\title{
Genetic testing
}

\section{Do doctors have it backward?}

Douglas M. Smith, MD

Neurology ${ }^{\circledR}$ 2019;92:e523-e526. doi:10.1212/WNL.0000000000006863

RELATED ARTICLE

\section{What did the authors study?}

There are many different types of genetic tests available to doctors treating epilepsy. Some of them are easy, low-cost tests that are less likely to find the cause of seizures. Some are much more expensive but are much more likely to get answers. When doing genetic tests, most epilepsy doctors start with the lower-cost tests first. If these do not find an answer, they often will order more expensive tests until an answer is found. We do not know if this is the best approach. ${ }^{1}$ In their article, "Diagnostic yield of genetic tests in epilepsy: a meta-analysis and cost-effectiveness study," Fernández et al. ${ }^{2}$ ask whether it would save money if we changed the order of genetic tests and did the most expensive tests first.

\section{How was the study done?}

The researchers first used information from many other studies to calculate how often each type of genetic test finds a useful answer. Then they used this information to calculate a cost per diagnosis. For example, if a test costs $\$ 100$ but only finds an answer in 1 of 20 people tested, then it costs $\$ 2,000$ to diagnose 1 person. If a different test costs $\$ 1,000$ but finds an answer in 1 of every 2 people tested, then it costs the same $\$ 2,000$ to diagnose each person, even though the test is much more expensive. Then they used computer simulations to make the same calculation on different sequences of tests. They compared how much it costs per diagnosis using the current approach of starting with the low-cost test first vs how much it would cost if doctors did the more expensive tests first.

\section{What did the study show?}

The first calculation found that the low-cost genetic test commonly used, a chromosomal microarray (CMA), found the cause of a person's epilepsy only $8 \%$ of the time. The typical "next step" in testing, or epilepsy panel (EP), found the answer $23 \%$ of the time. The most comprehensive and most expensive test, whole-exome sequencing (WES), found the answer $45 \%$ of the time.

The authors found that even though WES is the most expensive test overall, it costs the least amount per diagnosis at $\$ 15,000$ per diagnosis. An EP costs slightly more money $(\$ 15,848)$ per diagnosis, and a CMA costs the most $(\$ 17,888)$. The authors also found that the least expensive sequence of testing is when doctors start with the most expensive test (WES), followed by an EP if the WES is normal, followed by a CMA if both the EP and WES tests are normal. However, when adjusting for the real world, the authors thought that the best sequence would be EP first, followed by CMA, and followed by WES if the others are normal.

\section{What does this mean?}

The world of genetic testing is changing very quickly, and the health care system is still trying to figure out the best way to do it. Doctors are also trying to figure out the best system; while we do not want to waste money on unnecessary tests, we want to do what is best for our patients. This study shows that what most doctors have been doing may not be what is best for our patients or

\section{Article}

Diagnostic yield of genetic tests in epilepsy: A metaanalysis and costeffectiveness study

Page 219 
for the health care system. It turns out that starting out with the low-cost test first ultimately costs more money overall because so many of those tests do not find an answer.

This study is a great start to convincing doctors and insurance companies to consider doing some of the more expensive tests first. However, the results need to be confirmed in the real world before this becomes common practice. Genetic testing is, and will continue to be, very much customized to each patient. As the costs to all of these tests are continuing to decrease, doctors will continue to ask what the smartest way is to finding answers for our patients.

\section{References}

1. Ream MA, Patel AD. Obtaining genetic testing in pediatric epilepsy. Epilepsia 2015; 56:1505-1514.

2. Fernández IS, Loddenkemper T, Gaínza-Lein M, Sheidley BR, Poduri A. Diagnostic yield of genetic tests in epilepsy: a meta-analysis and cost-effectiveness study. Neurology 2019;92:e418-e428. 


\section{About epilepsy and genetics}

Douglas M. Smith, MD

Neurology ${ }^{\circledR}$ 2019;92:e523-e526. doi:10.1212/WNL.0000000000006863

\section{What are seizures?}

The cells of your brain use chemicals and a kind of electricity to talk to each other. Most of the time, this electricity is like a room of people talking - there is constant chatter but none of the voices stand out. If a group of cells start talking loudly together, they can make a sound that can be heard above the crowd. It is this grouping together of electrical voices, all saying the same thing, that cause seizures. This can look like many different things, depending on how many cells are talking, how loudly they are talking, and what those cells normally are up to.

This is why there are many different types of seizures. Most people have heard of the "grand mal" type seizure, where a person becomes stiff all over and has shaking movements of all of their arms and legs. Other seizures may look similar to this, only involving one half of the body. People may or may not lose consciousness during a seizure. A seizure can be nothing more than a muscle jerk, over in less than a second. It can be a few seconds of staring off. It can change a lot from person to person.

\section{What is epilepsy?}

People have seizures for different reasons. Some kids have seizures when they have a high fever. Some people with diabetes have seizures when their blood sugar gets low. These seizures are provoked, or set off, by something else. It is the fever or the blood sugar that is the problem, not the brain. In epilepsy, there is nothing provoking the seizures. Seizures happen for no good reason. In epilepsy, doctors use seizure medications to prevent seizures. In provoked seizures, doctors usually do not use seizure medications.

\section{What causes epilepsy?}

There are a lot of different reasons why people can get epilepsy. Sometimes, epilepsy happens after there is an injury to the brain. For example, epilepsy can happen after a concussion, after a stroke, or after a brain infection. Sometimes, doctors can tell the cause of epilepsy by taking a picture of the brain. However, for many people, no brain injury ever happened, and there is nothing wrong on the picture of their brain. For many of these people, their epilepsy is genetic.

\section{What do you mean by genetic epilepsy?}

The information of what makes you look like you and act like you is in your genes. Genes are why your children look like you and have similar medical problems. These genes are basically sentences found in 46 huge books written in a foreign language, found in every single cell in your body. There are a lot of changes in these genes that can cause epilepsy. Some changes are like typos, where only one letter is wrong. Some changes are when a book is missing several pages, or has a few too many.

In some cases, when epilepsy is genetic, it runs in the family. In many cases, it does not. Doctors can do many types of genetic tests to find out whether someone's epilepsy is genetic. Unfortunately, these tests are limited, and doctors need to pick certain parts of the 
books to read. This means that a "normal" genetic test does not mean that someone's epilepsy is not genetic. It may mean that it is hidden in a different part of one of the books. Doctors hope to be able to read all 46 books with their genetic testing, but this is likely many years away.

\section{For more information}

Brain \& Life

brainandlife.org/

\section{Epilepsy Foundation of America}

epilepsy.com/learn/diagnosis/genetic-testing

International League Against Epilepsy

epilepsydiagnosis.org/aetiology/genetic-groupoverview.html 


\section{Neurology}

Genetic testing: Do doctors have it backward?

Douglas M. Smith

Neurology 2019;92;e523-e526

DOI 10.1212/WNL.0000000000006863

This information is current as of January 28, 2019

\section{Updated Information \&} Services

References

Permissions \& Licensing

Reprints including high resolution figures, can be found at: http://n.neurology.org/content/92/5/e523.full

This article cites 2 articles, 1 of which you can access for free at: http://n.neurology.org/content/92/5/e523.full\#ref-list-1

Information about reproducing this article in parts (figures,tables) or in its entirety can be found online at:

http://www.neurology.org/about/about_the_journal\#permissions

Information about ordering reprints can be found online:

http://n.neurology.org/subscribers/advertise

Neurology ${ }^{\circledR}$ is the official journal of the American Academy of Neurology. Published continuously since 1951 , it is now a weekly with 48 issues per year. Copyright @ 2019 American Academy of Neurology. All rights reserved. Print ISSN: 0028-3878. Online ISSN: 1526-632X.

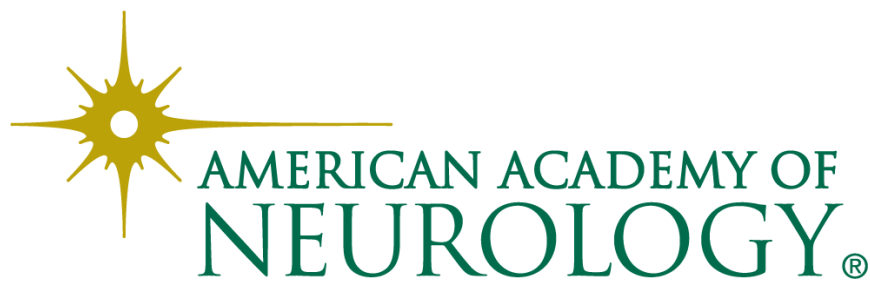

